\title{
The Belt and Road Initiative and the Law of the Sea: an Introduction
}

\author{
Keyuan Zou
}

\section{1 Introduction}

The Belt and Road Initiative (BRI) was put forward by Chinese President Xi Jinping in the year of 2013 when he visited Central Asia and Indonesia respectively. In accordance, the Belt refers to the "Silk Road Economic Belt" which is land based while the Road means the "21st-Century Maritime Silk Road" which is ocean based. That is why it is also called "One Belt, One Road" (овов). ${ }^{1}$ The Initiative focuses on cooperation between China and countries along the belt and road and provides new impetus and practical paths for intra- and interregional connectivity. China's National Development and Reform Commission, Ministry of Foreign Affairs and Ministry of Commerce jointly released a document in March 2015 that offered insights in the China-initiated vision and endeavors. ${ }^{2}$ As for the 21st Century Maritime Silk Road, it focuses on using Chinese coastal ports to link China with Europe through the South China Sea and the Indian Ocean and also to connect China with the South Pacific Ocean through the South China Sea. ${ }^{3}$ It is to be noted that the Silk Road Economic Belt on land also has maritime implications, for example, connecting China to the Baltic through Central Asia, Russia and Europe. ${ }^{4}$ Moreover, in addition to connectivity between land and sea, there are rights enjoyed by the land-locked states under international law, which will be discussed in this volume. Since 2013, there has been a discussion on BRI in academia and some are concerning law and policy dimensions. However, unlike the existing literature on BRI in general legal perspective, ${ }^{5}$ this book focuses more specifically on the maritime implications of the BRI in the context of the international law of the sea.

1 In this volume, both terms "BRI" and "ОвоR" are used but mean the same thing.

2 "Vision and Actions on Jointly Building Silk Road Economic Belt and 21st Century Maritime Silk Road", available at http://en.ndrc.gov.cn/newsrelease/201503/t20150330_669367.html.

3 Ibid.

4 Ibid.

5 For example, Yun Zhao (ed.), International Governance and the Rule of Law in China under the Belt and Road Initiative (Cambridge University Press, 2018); and Julien Chaisse and Jędrzej Górski (eds.), The Belt and Road Initiative: Law, Economics, and Politics (Brill, 2018). 
The 1982 United Nations Convention on the Law of the Sea has established the maritime order of the international community by providing a general legal framework governing maritime spaces and human activities at sea. Though it is not comprehensive covering all aspects of the sea and oceanic activities, the Convention is widely recognised as a "Constitution for the Oceans". 6 Therefore, all ocean-related activities generating from the Maritime Silk Road (MSR) projects in the cooperation between China and other countries along the MSR are subject to the LOSC governance, in particular between the countries that are parties to the Convention.

The book contains five parts respectively addressing the relationship between the BRI and the use of the oceans, sea lanes of communication and navigational safety, marine energy and sea ports, maritime law enforcement and cooperation, and access of the land-locked states to the sea.

Part 1 contains two chapters articulating the general framework on how the use of the oceans can be undertaken in the context of the BRI. The chapter contributed by Seokwoo Lee and Hee Eun Lee discusses the implications of the BRI and maritime economic cooperation in East Asia from a South Korean perspective. While BRI is an example of a "pan-Asian initiative" for Asian regional connectivity, South Korea has also advocated for this kind of regional connectivity calling for the building of a "Silk Road Express" to connect South Korea with Europe through Central Asia along with a maritime route linking the Northeast Sea Route with Eurasia. As the authors point out, "for a country like South Korea that is dependent upon international trade through the carriage of goods by sea, the implications of the BRI on the whole and the MSR in particular are crucial". ${ }^{7}$ On the other hand, South Korea needs to address the challenges posed by the BRI skilfully and steadfastly as the potential economic benefits are too great to ignore.

Following is the chapter by Renping Zhang who observes the legal implications of the BRI for ocean uses. The BRI plays a key role in maritime sustainable development for both China and those countries along the BRI. Both the

6 "A Constitution for the Oceans", Remarks by Tommy T.B. Koh, of Singapore, President of the Third United Nations Conference on the Law of the Sea, in United Nations, The Law of the Sea: United Nations Convention on the Law of the Sea with Index and Final Act of the Third United Nations Conference on the Law of the Sea (New York: United Nations, 1983), at xxxiii.

7 See Chapter 2 of this book. 
maritime and shipping industries play pivotal roles in the BRI and MSR. However, the great legal differences among countries of the road surely bring serious challenges to the BRI. This chapter firstly introduces the 21st Century MSR and its significance, and points out the pivotal roles the maritime and shipping industries plays in the process of the road construction. Secondly, the chapter explains the shipping-related legal implications for the use of oceans. Finally, the implication of the LOSC in relation to the implementation of IMO conventions is considered and analysed with a view to possible solutions to some issues arising from the MSR construction.

There are three chapters in Part 2 concerning maritime security and safety issues. The chapter contributed by Ted McDorman discusses the legal issues concerning international navigational rights and obligations in the Arctic waters, particularly the Northwest Passage embedded within the Canadian Arctic archipelago and the Northern Sea Route along the Arctic coast of Russia. The second chapter in this part is contributed by Suk Kyoon Kim and concerning the safety of passenger ships. As coastal and marine tourism and recreation activities have been increasing in Northeast Asia, the safety of passenger ships has become a serious concern. As seen in the Sewol ferry disaster in Korea in April 2014, the risk of maritime accidents by ferry boats which carry many passengers is high. The growth of maritime tourists and passengers also create increasing maritime accidents. This chapter explores the safety of passenger ships and related issues, focusing on Korea's enhanced safety measures in the wake of the Sewol ferry disaster. The last chapter of this part contributed by Tony Carty discusses China's dilemma in the South China Sea in the context of the BRI. While the US-China rivalry in the South China Sea is worrying, this sea area becomes strategically less significant when the connectivity between China and Europe through the Eurasian landmass. Germany is prepared to coordinate the impact of the BRI on the European Union and to collaborate with China in a global sustainable development policy. Thus China needs to see the advantage of winning both the US and a German-led Europe to a positive and enthusiastic support of its BRI projects.

In Part 3, the key issues of energy use and port connectivity of the BRI are addressed in three chapters. The chapter on sustainable use of energy is contributed by Yen-Chiang Chang. As we know, Chinese President Xi Jinping, while addressing to the United Nations Sustainable Development Summit, proposed the establishment of a Global Energy Interconnection to facilitate efforts meeting the global power demand, with clean and green alternatives in 2015. The Global Energy Interconnection conforms to the tendency of global energy reform and the needs of economic development; it represents a solution to the unbalanced distribution of renewable energy worldwide. This 
chapter introduces the concept of the Global Energy Interconnection and its implications for China and focuses on the additional references regarding China's energy legal system contributing to the systematic regulations concerning marine renewable energy development in China.

The chapter contributed by Ling Zhu explores the role of sea ports in the Belt and Road strategy and discusses the importance of sea ports in general, as well as their importance to China. It focuses on three specific aspects: (1) the role of sea ports in Chinese law; (2) the role of sea ports in international law; and (3) the role of sea ports in the Belt and Road strategy. The chapter concludes that the Belt and Road strategy will provide great stimulus for sea ports to play an even more proactive role in facilitating maritime logistics and international trade, as well as in maintaining maritime safety and security, environmental protection and other important aspects. Followed is the chapter also concerning maritime connectivity contributed by Zhihua Zheng. In the last few decades, maritime transport law has been in a fragmental state. It is not only harmful to the protection of safe transactions, but also creates unfair competitive situation. This chapter analyzes the necessity and possibility of harmonization of transport law under the Belt and Road Initiative, and points out that harmonization will help to eliminate unfair competition and meet the needs of efficient and orderly transportation and logistics.

Part 4 deals with maritime law enforcement with three chapters too. The chapter contributed by Warwick Gullett observes fisheries law enforcement cooperation through State practice. Cooperation among States is the key principle that underpins the LOSC and an important approach to the management of ocean resources. Fishing is the most ancient and enduring ocean activity. It evolves as new technologies emerge and fishing resources are discovered or alter in their distribution or abundance. There are challenges in ensuring adequate policing of fishing activities because of these dynamics and the oftentimes lucrative nature of fishing and its occurrence far offshore and sometimes in contested waters. An objective all coastal States should share is ensuring efficient use of expensive surveillance and enforcement assets. This chapter considers how bilateral cooperation can be developed to maximise the effectiveness of fisheries management measures. It examines Australia/France and China/UsA examples of bilateral cooperation in the enforcement of fisheries laws and suggests how States can develop cooperative fisheries management measures with neighbouring States. This approach would maximise the potential to achieve effective regional fisheries management and support efforts to achieve cooperation and avoid conflict in other marine sectors.

The second chapter in this part contributed by Vasco Becker-Weinberg focuses on maritime cooperation in the Mediterranean and Red Seas in the 
context of the BRI. Like the South China Sea, the Mediterranean and the Red Seas are semi-enclosed seas that include some of the world's most important seaways. Although very different in size, particularly being the Mediterranean Sea the largest sea in the world, both the Mediterranean and Red Seas share common challenges, particularly concerning safeguarding navigation through its straits, as well as maritime safety and security. These are challenges of the international community as a whole, and not only of the coastal States of the Mediterranean and Red Seas. It is precisely in this respect that the BRI may constitute an important global effort for the purpose of enhancing maritime cooperation in the Mediterranean and Red Seas. This chapter examines the overarching legal framework applicable to maritime cooperation in the Mediterranean and Red Seas, taking into consideration the wider interests of the international community as a whole regarding the freedom of navigation and the protection and preservation of the marine environment.

The final chapter in this part contributed by Chen-ju Chen opens a more general discussion on maritime law enforcement and cooperation in connection to the Belt and Road Initiative. Adopted in 1982 and based on the zonal approach, the LOSC has established both the coastal and other States' rights and obligations in internal waters, territorial seas, contiguous zones, exclusive economic zones, continental shelves, and the high seas. Within this framework, coastal States enjoy full sovereignty in the internal waters and territorial seas. However, on the high seas - though generally not effective - flag States enjoy exclusive jurisdiction. Thus, the LOSC Article 218(1) offers port States opportunities to develop a regional enforcement mechanism. Further established are the regional MoUs on the Port State Control. Among these MoUs, following the 1982 Paris MoU on Port State Control in Europe and the North Atlantic Ocean, the Tokyo MoU on Port State Control in the Asia-Pacific region was signed in 1993. Being one of the Tokyo MoU Members, the People's Republic of China (PRC) has been the most active enforcer of the Tokyo MoU. In addition, to build a transnational economic belt and zone linking the major civilizations of Asia, Europe and Africa, the PRC proposed the BRI in 2013. Given the abovementioned experiences of the PRC in the Port State Control system, this chapter considers the BRI as a prime opportunity for States' maritime authorities within this network to further cooperate with each other and enforce the Port State Control.

In the last part - Part 5, access of oceans by land-locked states is discussed in two chapters. The first chapter contributed by a former judge at ITLOS Helmut Tuerk is on the rights of land-locked States. Since the BRI covers both the land and the sea, it is more significant for the land-locked countries such as those in Central Asia to get access to the sea for their economic development 
and benefits. As Judge Tuerk observes, the existing legal regime for the rights of landlocked States as recognized by the LOSC is a mixed picture. For navigation and port access, there is no problem for these States. However, the rights of landlocked States to participate in the exploitation of the living resources of the EEZ as well as their rights regarding marine scientific research seem to have been largely if not totally fallen into oblivion. As to the right to benefitsharing of minerals to be derived from the international seabed "Area", the landlocked States, like the rest of the international community, find themselves in a waiting position.

The second chapter of this part and also the final chapter of the book is contributed by Anastasia Telesetsky who attempts to propose innovatively an equitable allocation of fish catch shares to land-locked developing States. This chapter suggests that the current status quo where land-locked developing States and their citizens derive no benefit from living marine resources of the high seas is inequitable, and offers an alternative by suggesting that some portion of any allocation within an RFMO as a recognition of the rights of all people to benefit from the sustainable harvest of highly migratory species should be assigned to those developing States that have no physical means of accessing to the high seas. While land-locked developing countries are unlikely to be assigned large numbers of catch shares that they can transfer, any catch shares that they receive are likely to be transferred to a highest bidder or a significant political ally. The ability for a State to unilaterally transfer its shares reflects a key recognition of the extent of a land-locked State's sovereign rights to conserve and manage high seas fisheries. This recognition that land-locked developing States have legitimate interests in the high seas may change some existing counter-productive behaviour of land-locked developing States. Even if the assignment of catch shares is minimal, transferable catch shares may provide more revenue to land-locked developing States than existing flagging arrangements. If catch share systems are introduced into tuna RFMOs, some portions of the original shares should be allocated to land-locked developing States to help fulfil the original promises of the LOSC "to promote the economic and social advancement of all peoples of the world".

\section{3}

\section{Conclusion}

The BRI possesses a huge potential in promoting economic development along its geographic coverage and also in promoting orderly and free flow of economic factors, highly efficient allocation of resources and deep integration of 
markets; encouraging the countries along the Belt and Road to achieve economic policy coordination and carry out broader and more in-depth regional cooperation of higher standards; and jointly creating an open, inclusive and balanced regional economic cooperation architecture that will promote economic development in all the participating countries. On the other hand, however, we have to realise that doubts and distrust still remain in some countries in regard to the real intention of China to put forward the Initiative and whether it is really a win-win plan for the participating countries and the whole international community. Therefore, the challenges to the BRI and difficulties in its implementation cannot be ignored. Moreover, in the maritime domain, it seems that more challenges are posed to the BRI as demonstrated in the discussions of this book. 